\title{
Local Bone Marrow Renin-Angiotensin System and COVID-19
}

\author{
Rafiye CIFTCILER ${ }^{1}$, Ali Erdinc CIFTCILER ${ }^{2}$, Ibrahim Celalettin HAZNEDAROGLU ${ }^{1}$ \\ ${ }^{1}$ Hacettepe University Faculty of Medicine, Department of Hematology, Ankara \\ ${ }^{2}$ Ortakoy State Hospital, Department of General Surgery, Aksaray, TURKEY
}

\begin{abstract}
For the first time on December 31, 2019, 27 cases of pneumonia of unknown etiology were detected in Wuhan City, Hubei province, China. The factor that caused this clinic was called Severe Acute Respiratory Syndrome Coronavirus 2 (SARS-CoV-2). In the following days, WHO officially named the disease caused by the new coronavirus as Coronavirus Disease 2019 (COVID-19). Patients infected with SARS-CoV-2 mostly applied to health centers with symptoms of dry cough, shortness of breath and fever. some patients have developed death-causing complications such as organ failure, septic shock, pulmonary edema, severe pneumonia, and Acute Respiratory Distress Syndrome (ARDS). SARS-CoV-2 infects patients by binding human Angiotensin Converting Enzyme 2 (ACE 2), causing to severe pneumonia and high mortality. Circulating RAS and local paracrin-autocrin-intracrin tissue-based RAS participate in numerous pathobiological events. Pro-inflammatory, pro-fibrotic, and pro-thrombotic consequences associated with local RAS activation have been detected at cellular and molecular level. Regenerative progenitor cell therapy in response to RAS-modulating pharmacotherapy in context of endothelial cell damage and regeneration emerged as an auxiliary therapy to improve regeneration of the vascular endothelium. The aim of this article is to evaluate the relationship between circulating and local angiotensin systems and COVID-19.
\end{abstract}

Keywords: Covid-19, Renin Angiotensin System, Hematopoiesis, Acute Respiratory Syndrome Coronavirus 2

ÖZET

\section{Lokal Kemik İliği Renin Anjiotensin Sistem ve COVID-19}

IIlk kez 31 Aralık 2019'da , Çin'in Hubei eyaleti, Wuhan şehrinde etyolojisi bilinmeyen 27 pnömoni vakası tespit edildi. Bu kliniğe neden olan ajana Şiddetli Akut Solunum Yolu Sendromu Coronavirus 2 (SARS-CoV-2) adı verildi. Sonraki günlerde DSÖ, yeni koronavirüsün neden olduğu hastalı̆̆ı Coronavirus Hastalığı 2019 (COVID-19) olarak adlandırdı. SARS-CoV-2 ile enfekte hastalar çoğunlukla kuru öksürük, nefes darlığı ve ateş semptomları olan sağlık merkezlerine başvurdu. Bazı hastalarda organ yetmezliği, septik şok, pulmoner ödem, şiddetli pnömoni ve Akut Solunum Sıkıntısı Sendromu (ARDS) gibi ölüme neden olan komplikasyonlar geliştiği gözlendi. SARS-CoV-2, hastaları insan Anjiyotensin Dönüştürücü Enzim 2'yi (ACE 2) bağlayarak enfekte ederek ciddi pnömoniye ve yüksek mortaliteye neden olur. Dolaşımdaki RAS ve lokal parakrin-otokrin-intrakrin doku kaynakı RAS birçok patobiyolojik olaya katılır. Lokal RAS aktivasyonu ile ilişkili pro-enflamatuar, pro-fibrotik ve pro-trombotik sonuçlar hücresel ve moleküler düzeyde tespit edilmiştir. Endotelyal hücre hasarı ve rejenerasyonu bağlamında RAS modüle edici farmakoterapiye yanıt olarak rejeneratif progenitör hücre tedavisi, vasküler endotelin rejenerasyonunu iyileştirmek için yardımcı bir tedavi olarak ortaya çıkmıştır. Bu makalenin amacı, dolaşımdaki ve lokal anjiyotensin sistemleri ile COVID 19 arasındaki ilişkiyi değerlendirmektir.

Anahtar Kelimeler: COVID-19, Renin Anjiotensin Sistem, Hematopoez, Akut Respiratuvar Sendrom Coronovirus 2 


\section{INTRODUCTION}

For the first time on December 31, 2019, 27 cases of pneumonia of unknown etiology were detected in Wuhan City, Hubei province, China. ${ }^{1}$ The causative agent was identified from throat swab specimen conducted by the Chinese Centre for Disease Control and Prevention on 7th January 2020. The factor that caused this clinic was called Severe Acute Respiratory Syndrome Coronavirus 2 (SARS-CoV-2). ${ }^{2}$ In the following days, WHO officially named the disease caused by the new coronavirus as Coronavirus Disease 2019 (COVID-19). ${ }^{3}$ Patients infected with COVID-19 mostly applied to health centers with symptoms of dry cough, shortness of breath and fever. The symptoms of most of the cases resolved spontaneously. However, some patients have developed death-causing complications such as organ failure, septic shock, pulmonary edema, severe pneumonia, and Acute Respiratory Distress Syndrome (ARDS). ${ }^{4}$ COVID-19 infects patients by binding human Angiotensin Converting Enzyme 2 (ACE 2), causing to severe pneumonia and high mortality. ${ }^{5}$ Increased ACE and Ang II have been shown to be poor prognostic factors for severe pneumonia. ${ }^{6}$ Many important pathobiological events such as apoptosis, cellular proliferative events, mobilization, angiogenesis, fibrosis in the cytokine network are affected by Renin Angiotensin System (RAS) molecules. ${ }^{7-10}$ If the RAS system is not in balance, this can lead to an exacerbation of acute severe pneumonia. All major RAS molecules including Renin, angiotensinogen, angiotensin receptors and ACE have been shown to be found in the BM microenvironment. ${ }^{11}$ Haznedaroglu et al. hypothesized that there is a locally active RAS in the BM that affects the growth, production, proliferation, and differentiation of hematopoietic cells. ${ }^{12}$ The aim of this article is to evaluate the relationship between circulating and local angiotensin systems, COVID-19 and hematopoiesis.

\section{COVID-19}

Coronaviruses were first defined in 1966 by Tyrell and Bynoe. ${ }^{13}$ Coronaviruses are enveloped, positive single- stranded large RNA viruses that infect many animals and humans. ${ }^{14}$ Based on their morphology as spherical virions with a core shell and surface projections resembling a solar corona. Therefore, they were called as coronaviruses. SARS-CoV-2 appears to be transmitted from animals to humans on the Huanan seafood market in Wuhan, China. ${ }^{14}$ The first clinical sign of SARSCoV-2- related disease COVID - 19 was pneumonia. Gastrointestinal symptoms and asymptomatic infections were also described. ${ }^{15}$ Studies to date have shown that a median incubation period of 3 days (range: 0-24 days). ${ }^{16}$ There are also people infected with SARS -CoV-2, which remain asymptomatic throughout the infection. In symptomatic patients, clinical manifestations of the disease usually begin in less than a week. Clinical symptoms such as fever, cough, nasal congestion, fatigue and other upper respiratory infections are observed in patients. Infection can progress to serious illness, accompanied by severe chest symptoms corresponding to dyspnea and pneumonia. These findings can be seen with computed tomography. ${ }^{16}$ Pneumonia usually occurs in the second or third week of a symptomatic infection. Important signs of viral pneumonia are decreased oxygen saturation and blood gas deviations. Changes that can be seen with chest x-rays and other imaging techniques, ground glass abnormalities, irregular consolidation, alveolar exudates and interlobular involvement are observed. Lymphopenia is common in patients and C-reactive protein and pro-inflammatory cytokines are elevated. ${ }^{14}$

\section{COVID-19 and Renin Angiotensin System}

In a recent hypothesis, it has been published that angiotensin receptor 1 (AT1R) inhibitors may be useful for COVID-19 infected patients with pneumonia. ${ }^{5}$ Based on this published knowledge, it was assumed that angiotensin II receptor blockers (ARB) present for clinical use may be potential drugs to control viral spread of the COVID-19. In a published observation, patients with hypertension using Losartan or Telmisartan tablets as antihypertensive have been shown to experience fewer cold and flu-like disease attacks. ${ }^{17}$ Losartan and Telmisartan severely bind to the AT1 receptors. ${ }^{18}$ The receptor binding domain for the spike protein of SARS-CoV-2, ACE2 was reported to be similar to the coronavirus strain involved in the 2002- 
2003 SARS outbreak. ${ }^{19}$ The receptor binding domains of these two coronaviruses show $72 \%$ amino acid sequence similarity. The molecular simulation also showed similar ternary structures. ${ }^{20}$ However, SARS-CoV-2 has higher affinity for ACE2 compared with SARS-CoV. ${ }^{20}$ It has been reported that binding of the coronavirus spike protein to ACE2, its cellular binding site, leads to ACE2 downregulation, which in turn results in excessive production of angiotensin by the related enzyme ACE, while less ACE2 is capable of converting it to the vasodilator heptapeptide angiotensin..$^{1-7}$ Thus, lung damage increases because AT1R due to angiotensin increases pulmonary vascular permeability and ultimately mediates increased lung pathology. ${ }^{21,22}$ Therefore, by treating patients infected with SARSCoV-2 chronically with AT1R blockers, higher ACE2 expression, although seemingly paradoxical, can protect them against acute lung damage. ${ }^{23}$

\section{COVID-19 and Hematopoiesis}

Fan et al. has shown that most patients have normal complete blood count (normal Hb, WBC and platelet count) and lactate dehydrogenase (LDH) when patients first apply to the hospital. Moderate or severe thrombocytopenia, which is common in other viral diseases, has not been observed in COVID-19. The study reported that, $28 \%$ of all patients presented with lymphopenia (acute lymphocyte count $\left.<1 \times 10^{9} / \mathrm{L}\right) .{ }^{24}$ Additionally, it was shown that patients in intensive care units have significantly lower CD45+, CD3+, CD4+, CD8+, CD19+ and CD16/56+ counts. ${ }^{24}$ Another study observed that most patients had high $\mathrm{C}$ reactive protein, erythrocyte sedimentation rate and normal procalcitonin level. In severe cases, D-dimer increased and lymphocytes gradually decreased. It was shown to have high inflammatory parameters in severe and critical patients. ${ }^{25}$ Another study showed that SARSCoV-2 directly infects secondary lymphoid organs to cause cell death. Immunofluorescence staining confirmed that viral nucleospicy protein can be found in ACE2 + cells, CD169 + macrophages. ${ }^{26}$ It can be considered as one of the causes of lymphopenia. Moreover, Wang et al. showed that T-cell lines were remarkably more susceptible to SARSCoV-2 infection when compared with SARS$\mathrm{CoV}^{27}$ In some other studies, patients had normal or lower white blood cell count, lymphopenia or thrombocytopenia, prolonged active thromboplastin time and increased C-reactive protein level. ${ }^{4,28,29}$ High white blood cell count, high neutrophil count, low lymphocyte count and high LDH values were observed in patients who were refeerred to intensive care unit. ${ }^{30}$

Inflammageing is the characteristic process of chronic inflammation that has been defined in elderly individuals, with an increase of inflammatory cytokine levels that correlate with morbidity and age-related diseases. ${ }^{31,32}$ The HSC network is closely linked to inflammatory processes as a manufacturer of congenital immune cells. Furthermore, HSCs express receptors required for the identification of dangers and a variety of cytokines and their receptors. ${ }^{33,34}$ In elderly individuals, a variety of factors such as interleukin 6 , interleukin 1 receptor antagonist, interleukin 18 , fibrinogen and $\mathrm{C}$ reactive protein all increase significantly. ${ }^{32}$ Aging is a proinflammatory condition. the immune response in older people is very exaggerated and insufficient to settle early. ${ }^{35}$ Leukocytosis, neutrophilia, cytokinemia are more prominent in patients with severe COVID-19. Therefore, various immunomodulatory treatments (chloroquine, anti IL-6 agents, corticosteroids) are thought to be successful in COVID-19. Of the cytokines produced by HSCs and progenitors, interleukin 6 appears to be important as a regulator of paracrine-style proliferations and myeloid differentiation, and as a myelopoiesis driver both in vitro and in vivo. ${ }^{34}$ Furthermore, tumor necrosis factor (TNF) added to cycling human HSCs both in vitro and in vivo compromises their ability to reconstitute immunodeficient mice and long-term cultures. This effect is mediated by the TNF receptor p55, which seems to assist HSC differentiation. ${ }^{36}$

\section{Hematopoiesis and Bone Marrow Renin Angiotensin System}

Circulating RAS and local paracrin-autocrin-intracrin tissue-based RAS participate in numerous pathobiological events. Pro-inflammatory, profibrotic, and pro-thrombotic consequences associated with local RAS activation have been detected at cellular and molecular level. Regenerative pro- 


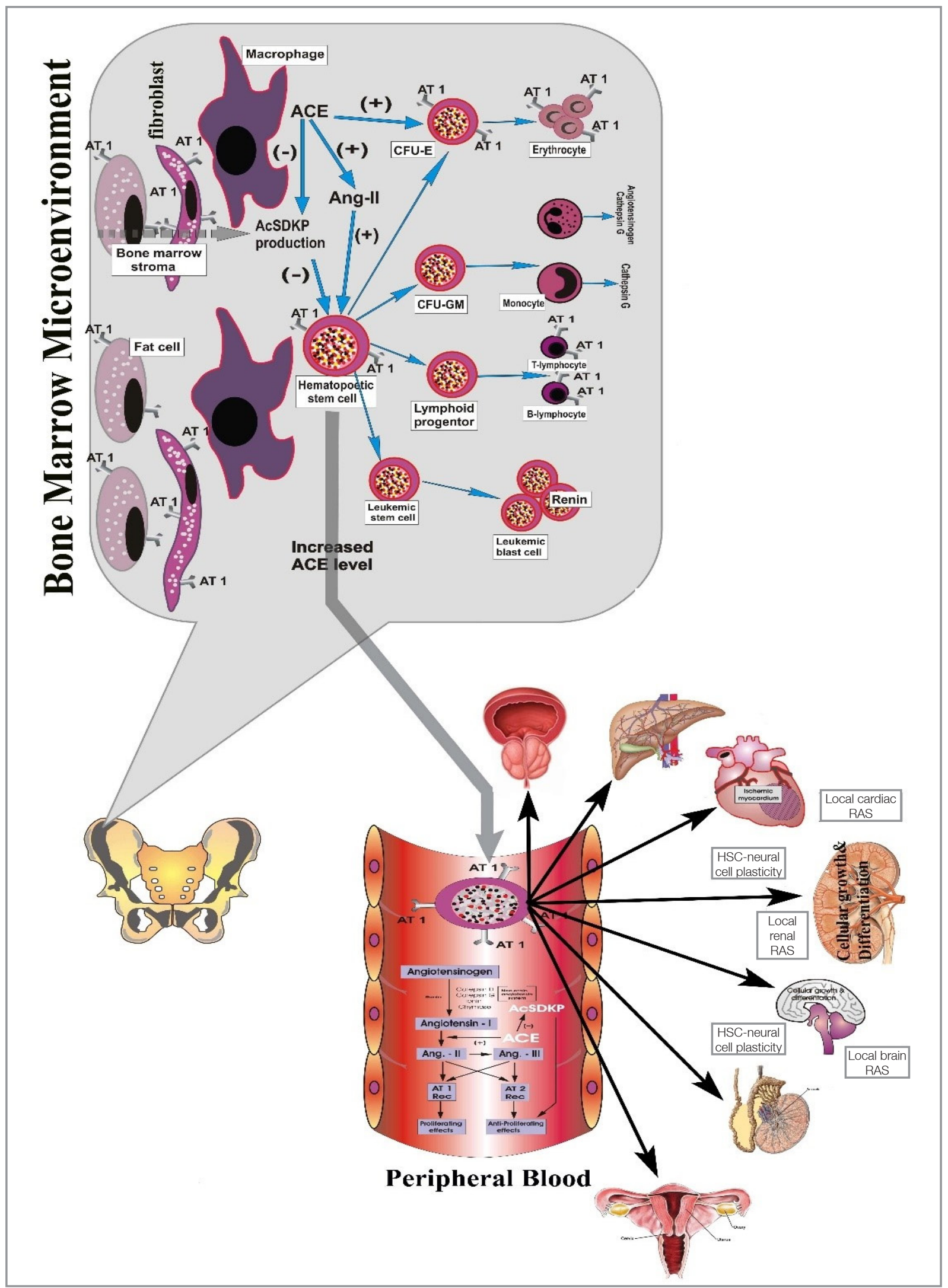

Figure 1. The effect of local RAS on hematopoiesis, as well as systemic circulation. (modified with permission from https://www. hindawi.com/journals/crp/2011/714515/fig1/). 
genitor cell therapy in response to RAS-modulating pharmacotherapy in context of endothelial cell damage and regeneration emerged as an auxiliary therapy to improve regeneration of the vascular endothelium. Major RAS molecules, including renin, angiotensinogen, angiotensin receptors and ACE are all found in the BM microenvironment. ${ }^{11}$ Haznedaroglu et al. first hypothesized that there exists a locally active RAS in the BM affecting the growth, production, proliferation and differentiation of hematopoietic cells as depicted in Figure $1 .^{12}$ Later, evidence of a local RAS in the bone marrow increased day by day. Locally active BM RAS affects important steps in physiological and pathological blood cell production by autocrine, paracrine and intracrine routes. ${ }^{7,8}$ The development of hematopoietic niche, myelopoiesis, erythropoiesis, thrombopoiesis and other cellular linage is controlled by local BM RAS peptides. ${ }^{37-40}$ Local RAS in the BM stromal niche controls important hematopoietic functions. ${ }^{8,11,37-39,41,42}$ Many important pathobiological events such as apoptosis, cellular proliferative events, mobilization, angiogenesis, fibrosis in the cytokine network are affected by RAS molecules. ${ }^{7-10} \mathrm{BM}$ stromal microenvironment includes AT1R and AT2R (angiotensin type 1 and type 2 receptors, respectively) and inhibitory tetrapeptide AcSDKP (N-acetyl-Ser-Asp-Lys-Pro). The major RAS effector agent angiotensin II (Ang II) exerts its effects on the hematopoietic system by activating the AT1Rs and AT2Rs, along with the BM microenvironment. ${ }^{7,8}$

Ang I, Ang II, Ac-SDKP and Ang 1-7 are secreted in different tissues and transferred to the $\mathrm{BM}$ through circulation. ACE converts Ang II from Ang I and reduces bioactive SP, Ac-SDKP and Ang 1-7. Mas, with the Ang 1-7 receptor, is detected in the BM. Peptides in RAS can stimulate hematopoietic cells. Furthermore, local BM RAS plays a role in the development, formation, proliferation and differentiation of hematopoietic progenitors.

\section{COVID-19, Renin Angiotensin System and Hematopoiesis}

ACE2 has a significant role in the RAS. The imbalance between ACE/Ang II/AT1R pathway and ACE2/Ang (1-7)/Mas receptor pathway in the
RAS leads to multi-system inflammation. ${ }^{5}$ Furthermore, local BM RAS is involved in the regulation of important peptides that control hematopoiesis. Local BM RAS has significant effects on hematopoietic systems, particularly on myeloid and eritroid cells. ${ }^{8,12,41}$ It has been proven in previous studies that there are important receptors of Ang 1-7 and MAS in the bone marrow stroma. ${ }^{43} \mathrm{BM}$ hematopoietic stem/progenitor cells (HSPCs) interact with the cells of secondary lymphoid organs, which control HSPC differentiation and maturation. ${ }^{44,45}$ On the other hand, ACE2 is the common binding site of both the SARS-CoV of the 20022003 SARS outbreak and possibly the SARSCoV-2 strain underlying the current COVID-19 outbreak. ${ }^{19}$ Moreover, angiotensin-induced AT1R causes increased pulmonary vascular permeability and thus mediates increased lung pathology. ${ }^{21,22} \mathrm{In}$ the light of all these findings, it is thought that RAS has great importance in terms of therapeutic targets in COVID-19. In a recent study, Liu et al. evaluated COVID-19 patients used ACEI, ARB, calcium channel blockers (CCB), beta blockers (BB), or thiazide to treat preexisting hypertension prior to the hospital and patients who did not take any of those drugs. In their meta-analysis, it was concluded that the use of ARB has positive effects on the morbidity and mortality of pneumonia. As a result of this metanalysis, elderly (age > 65) COVID-19 patients with hypertension comorbidity taking ARB medications commented that they may be less likely to develop severe lung disease compared to patients not taking antihypertension medication. ${ }^{46}$

\section{Promising Treatment of COVID-19 with Soluble ACE2}

It is reported that the genome structure of SARSCoV-2 looks like those of other betacoronaviruses. ${ }^{47}$ The long replicase ORF1ab gene of SARS$\mathrm{CoV}-2$ is over $21 \mathrm{~kb}$ in length. It includes 16 predicted non-structural proteins and a number of downstream ORFs likely of similar function to those of SARS-CoV. ${ }^{47}$ Many drug development projects, including the development of vaccines, focus on ACE2-SARS-CoV-2 Spike interactions. Wang et al. reported that the crystal structure of C-terminal domain of SARS-CoV-2 spike protein 
in complex with human ACE2 (hACE2), which shows a hACE2-binding style alike overall to that observed for SARS-CoV. ${ }^{48}$ ACE2 protects the lung from injury from the SARS-CoV infections. ACE2 has also been identified as a key receptor for SARSCoV-2 infections. ${ }^{49}$ ACE2 is expressed in various tissues including heart, kidneys, blood vessels, intestine and alveolar epithelial cells. ${ }^{50-56}$ It has been suggested that inhibition of this interaction can be used in the treatment of patients with COVID19. Monteil et al. showed that clinical grade human recombinant soluble (hrs) ACE2 can significantly inhibit SARS-CoV-2 infections and reduce viral load by a factor of 1,000-5,000. It has also been shown that SARS-CoV-2 can directly infect human blood vessel organoids and human kidney organoids designed to be inhibited by hrsACE2. ${ }^{49}$

\section{Hypotheses}

In the light of all this data, the initial stage of viral attack to the body shall be called as "COVID-19 infection" but following "virus induced immune depression' and impaired disproportionate macrophage activation' should be called as "COVID-19 syndrome", which is an immune disorder rather than infection. A temporary recommendation based on existing therapeutics that will probably be resistant to new coronavirus mutations can be used to reduce the aggression and mortality rate of SARS-CoV-2 virus infections. This idea is based on observations that the ACE2 very likely serves as the binding site for SARS-CoV-2, the strain implicated in the current COVID-19 epidemic, similarly to strain SARS-CoV (23). All this discussed information evaluates the idea of treating AT1R blockers as a temporary treatment for SARS-CoV-2 infections. It will also guide future research.

\section{Conflict of Interests}

The authors of this paper have no conflict of interests, including specific financial interests, relationships, and/or affiliations relevant to the subject matter or materials included.

\section{Role of the funding source}

None.

\section{REFERENCES}

1. Lu H, Stratton CW, Tang YW. Outbreak of pneumonia of unknown etiology in Wuhan China: the mystery and the miracle. J Med Virol 92: 401-402, 2020.

2. Sohrabi C, Alsafi Z, O'Neill N, et al. World Health Organization declares global emergency: A review of the 2019 novel coronavirus (COVID-19). Int J Surg 76: 71-76, 2020.

3. Organization WH. WHO Director-General's remarks at the media briefing on 2019-nCoV on 11 February 2020. https:// www.who.int/dg/speeches/detail/who-director-general-sremarks-at-the-media-briefing-on-2019-ncov-on-11-february-2020.

4. Chen N, Zhou M, Dong X, et al. Epidemiological and clinical characteristics of 99 cases of 2019 novel coronavirus pneumonia in Wuhan, China: a descriptive study. Lancet 395: 507-513, 2020.

5. Sun M, Yang J, Sun $Y$, et al. Inhibitors of RAS might be a good choice for the therapy of COVID-19 pneumonia. DERGI ADI: Zhonghua Jie He He Hu Xi Za Zhi 43: E014, 2020.

6. Xudong X, Junzhu C, Xingxiang W, et al. Age-and genderrelated difference of ACE2 expression in rat lung. Life Sci 78 : 2166-2171, 2006

7. Haznedaroglu IC, Beyazit Y. Pathobiological aspects of the local bone marrow renin-angiotensin system: a review. J Renin Angiotensin Aldosterone Syst 11: 205-213, 2010.

8. Haznedaroglu IC, Öztürk MA. Towards the understanding of the local hematopoietic bone marrow renin-angiotensin system. Int J Biochem Cell Biol 35: 867-880, 2003.

9. Durik M, Sevá Pessôa B, Roks AJJCS. The renin-angiotensin system, bone marrow and progenitor cells. Clin Sci 123: 205223, 2012.

10. Heringer-Walther S, Eckert K, Schumacher S-M, et al. Angiotensin-(1-7) stimulates hematopoietic progenitor cells in vitro and in vivo. Haematologica 94: 857-860, 2009.

11. Strawn WB, Richmond RS, Ann Tallant E, et al. Renin-angiotensin system expression in rat bone marrow haematopoietic and stromal cells. Br J Haematol 126: 120-126, 2004.

12. Haznedaroglu I, Tuncer S, Gürsoy MA. A local renin-angiotensin system in the bone marrow. Lancet 46: 507-510, 1996.

13. Tyrrell D, Bynoe MJL. Cultivation of viruses from a high proportion of patients with colds. Lancet 287: 76-77, 1966.

14. Velavan TP, Meyer CG. The COVID-19 epidemic. Trop Med Int Health 25: 278-280, 2020.

15. Chan J, Yuan S, Kok K, et al. A familial cluster of pneumonia associated 21 with the 2019 novel coronavirus indicating person-to-person transmission: a 22 study of a family cluster. Lancet 15: 514-523, 2020.

16. Guan W-j, Ni ZY, Hu Y, et al. Clinical Characteristics of Coronavirus Disease 2019 in China. N Engl J Med 382: 17081720, 2020 
17. Kickbusch I, Leung G. Response to the emerging novel coronavirus outbreak. BMJ 368: m406, 2020.

18. Burnier M, Brunner H. Angiotensin II receptor antagonists. Lancet 355: 637-645, 2000.

19. Lu R, Zhao X, Li J, et al. Genomic characterisation and epidemiology of 2019 novel coronavirus: implications for virus origins and receptor binding. Lancet 395: 565-574, 2020.

20. Chen $Y$, Guo Y, Pan Y, et al. Structure analysis of the receptor binding of 2019-nCoV. Biochem Biophys Res Commun 525: 135-140, 2020.

21. Imai $Y$, Kuba K, Rao S, et al. Angiotensin-converting enzyme 2 protects from severe acute lung failure. Nature 436: 112116, 2005.

22. Kuba K, Imai $Y$, Rao $S$, et al. A crucial role of angiotensin converting enzyme 2 (ACE2) in SARS coronavirus-induced lung injury. Nat Med 11: 875-879, 2005.

23. Gurwitz D. Angiotensin receptor blockers as tentative SARSCoV-2 therapeutics. Drug Dev Res 2020 Mar 4. doi: 10.1002/ ddr.21656

24. Fan BE, Chong VCL, Chan SSW, et al. Hematologic parameters in patients with COVID-19 infection. Am J Hematol 95: E131-E134, 2020.

25. Wang $Y$, Wang $Y$, Chen $Y$, et al. Unique epidemiological and clinical features of the emerging 2019 novel coronavirus pneumonia (COVID-19) implicate special control measures. J Med Virol 2020 Mar 5. doi: 10.1002/jmv.25748

26. Feng Z, Diao B, Wang R, et al. The novel severe acute respiratory syndrome Coronavirus 2 (SARS-CoV-2) directly decimates human spleens and lymph nodes. 2020 Mar 31. doi: https://doi.org/10.1101/2020.03.27.20045427 (Preprint at medRxiv))

27. Wang $X, X u$ W, Hu G, et al. SARS-CoV-2 infects T lymphocytes through its spike protein-mediated membrane fusion. CMI 2020 Apr 7. doi: 10.1038/s41423-020-0424-9

28. Guan W-j, Ni Z-y, Hu Y, et al. Clinical characteristics of coronavirus disease 2019 in China. N Engl J Med 382: 17081720, 2020.

29. Huang C, Wang Y, Li X, et al. Clinical features of patients infected with 2019 novel coronavirus in Wuhan, China. Lancet 395: 497-506, 2020.

30. Wang D, Hu B, Hu C, et al. Clinical characteristics of 138 hospitalized patients with 2019 novel coronavirus-infected pneumonia in Wuhan, China. JAMA 323: 1061-1069, 2020.

31. Franceschi C, Campisi J. Chronic inflammation (inflammaging) and its potential contribution to age-associated diseases. J Gerontol A Biol Sci Med Sci 69: 4-9, 2014.

32. Ferrucci L, Corsi A, Lauretani $F$, et al. The origins of agerelated proinflammatory state. Blood 105: 2294-2299, 2005.

33. Takizawa H, Boettcher S, Manz MG. . Demand-adapted regulation of early hematopoiesis in infection and inflammation. Blood 119: 2991-3002, 2012.
34. Zhao JL, Ma C, O'Connell RM, et al. Conversion of danger signals into cytokine signals by hematopoietic stem and progenitor cells for regulation of stress-induced hematopoiesis. Cell stem cell 14: 445-459, 2014.

35. Calder PC, Bosco N, Bourdet-Sicard R, et al. Health relevance of the modification of low grade inflammation in ageing (inflammageing) and the role of nutrition. Ageing Res Rev 40: 95-119, 2017.

36. Dybedal I, Bryder D, Fossum A, et al. Tumor necrosis factor (TNF)-mediated activation of the p55 TNF receptor negatively regulates maintenance of cycling reconstituting human hematopoietic stem cells. Blood 98: 1782-1791, 2001.

37. Hubert C, Savary K, Gasc J-M, Corvol P. The hematopoietic system: a new niche for the renin-angiotensin system. Nat Clin Pract Cardiovasc Med 3: 80-85, 2006.

38. Lin C, Datta V, Okwan-Duodu D, et al. Angiotensin-converting enzyme is required for normal myelopoiesis. The FASEB 25: 1145-1155, 2011.

39. Kato H, Ishida J, Imagawa S, et al. Enhanced erythropoiesis mediated by activation of the renin-angiotensin system via angiotensin II type 1a receptor. The FASEB 19: 2023-2025, 2005.

40. Kwiatkowski BA, Richard RE. Angiotensin II receptor-associated protein (AGTRAP) synergizes with Mpl signaling to promote survival and to increase proliferation rate of hematopoietic cells. Blood 114: 3606, 2009.

41. Haznedaroglu IC, Beyazit Y. Local bone marrow renin-angiotensin system in primitive, definitive and neoplastic haematopoiesis. Clin Sci 124: 307-323, 2013.

42. Park TS, Zambidis ET. A role for the renin-angiotensin system in hematopoiesis. Haematologica 94: 745-747, 2009.

43. Shen XZ, Bernstein KE. The peptide network regulated by angiotensin converting enzyme (ACE) in hematopoiesis. Cell Cycle 10: 1363-1369, 2011.

44. Swirski FK, Nahrendorf M, Etzrodt M, et al. Identification of splenic reservoir monocytes and their deployment to inflammatory sites. Science 325: 612-616, 2009.

45. Malhotra D, Fletcher AL, Turley SJ. Stromal and hematopoietic cells in secondary lymphoid organs: partners in immunity. Immunol Rev 251: 160-176, 2013.

46. Liu Y, Huang F, Xu J, et al. Anti-hypertensive Angiotensin II receptor blockers associated to mitigation of disease severity in elderly COVID-19 patients. BMJ 2020 Mar 27. doi: https:// doi.org/10.1101/2020.03.20.20039586 ((Preprint at medRxiv)

47. Zhang Y-Z, Holmes EC. A Genomic perspective on the origin and emergence of SARS-CoV-2. Cell 181: 223-227, 2020.

48. Wang $Q$, Zhang $Y$, Wu $L$, et al. Structural and functional basis of SARS-CoV-2 entry by using human ACE2. Cell 181: 1-11, 2020. 
International Journal of Hematology and Oncology

49. Monteil $\mathrm{V}, \mathrm{K}$ won $\mathrm{H}$, Prado $\mathrm{P}$, et al. Inhibition of SARS-CoV-2 infections in engineered human tissues using clinical-grade soluble human ACE2. Cell 181: 1-9, 2020.

50. Zhao Y, Zhao Z, Wang $Y$, et al. Single-cell RNA expression profiling of ACE2, the putative receptor of Wuhan 2019-nCov. 2020 Jan 26. doi: https://doi. org/10.1101/2020.01.26.919985 (Preprint at medRxiv)

51. Crackower MA, Sarao R, Oudit GY, et al. Angiotensin-converting enzyme 2 is an essential regulator of heart function. Nature 417: 822-828, 2002.

52. Danilczyk U, Penninger JM. Angiotensin-converting enzyme ॥ in the heart and the kidney. Circ Res 98: 463-471, 2006.

53. Ding $Y$, He L, Zhang $Q$, et al. Organ distribution of severe acute respiratory syndrome (SARS) associated coronavirus (SARS-CoV) in SARS patients: implications for pathogenesis and virus transmission pathways. J Pathol 203: 622-630, 2004.

54. Gu J, Gong E, Zhang B, et al. Multiple organ infection and the pathogenesis of SARS. JEM 202: 415-424, 2005.

55. Zhang $\mathrm{H}$, Penninger JM, Li Y, et al. Angiotensin-converting enzyme 2 (ACE2) as a SARS-CoV-2 receptor: molecular mechanisms and potential therapeutic target. Intensive Care Med 46: 586-590, 2020.

56. Hamming I, Timens W, Bulthuis M, et al. Tissue distribution of ACE2 protein, the functional receptor for SARS coronavirus. A first step in understanding SARS pathogenesis. J Pathol 203: 631-617, 2004.

\section{Correspondence:}

Dr. Rafiye CIFTCILER

Hacettepe Universitesi, Tip Fakultesi

Hematoloji Anabilim Dali

06100 Sihhiye, ANKARA / TURKEY

Tel: (+90-0312) 3053050

(+90-505) 5831798

Fax: (+90-0312) 3051614

e-mail: rafiyesarigul@gmail.com

\section{ORCIDs:}

Rafiye Çiftçiler:

0000-0001-5687-8531

Ali Erdinç Ciftçiler:

0000-0001-7612-2707

Ibrahim Celalettin Haznedaroğlu: 0000-0001-8028-9462 